\title{
KAJIAN PEMASARAN IKAN PATIN ASAP DI KABUPATEN BOGOR JAWA BARAT STUDI KASUS ANIMO MASYARAKAT KABUPATEN BOGOR TERHADAP KONSUMSI PRODUK IKAN PATIN ASAP
}

\author{
Oleh \\ Suratman, Sobariah \\ Dosen Jurusan penyuluhan Perikanan Sekolah tinggi Perikanan
}

\begin{abstract}
ABSTRAK
Kajian pemasaran ikan patin asap di Kabupaten Bogor Jawa Barat studi Kasus Animo Masyarakat Kabupaten Bogor terhadap Konsumsi Produk Ikan Patin Asap gambaran tentang konsumen yang sering mengubah - ubah keinginan dan implikasiimplikasi penting dalam keputusan pemasaran, dewasa ini lingkungan pemasaran disadari atau tidak oleh pelaku pasar/bisnis cendrung berubah lebih cepat dan kompleks dibandingkan beberapa dasawarsa sebelumnya. Kondisi ini bisa dipahami karena dunia bisnis selalu berubah secara dinamis sehingga pemasar perlu berada dalam jarak yang dekat dengan konsumen dan mengetahui tingkah laku konsumen yang dilayani. Keadaan ini juga dimotori oleh adanya globalisasi perdagangan dan perkembangan teknologi yang menjadi faktor gerak.

Faktor perilaku konsumen dalam mengkonsumsi barang kebutuhan sehari-hari semakin cenderung bervariasi dan berubah dengan cepat. Konsumen dapat dengan mudah beralih ke sumber protein yang diinginkan karena tawaran produk yang semakin banyak, yang tidak hanya berasal dari suatu sumber protein hewani yang bersaing dalam segi harga, kualitas dan kuantitas. Manajer perlu memiliki kemampuan untuk melihat lebih dulu sebelum melangkah atau "look before you leap"

Mengkaji pengaruh motivasi konsumen secara individu terhadap daya beli dan konsumsi ikan patina asap di kabupaten Bogor, dengan menganalisis marjin tataniaga dalam penyebarannya pada setiap lembaga perantara yang terlibat pada sistem pemasaran yang dilakukan. Namun perilaku konsumen dapat dimengerti, walau tidak sempurna, maka melalui penelitian ini tetap diusahakan dan didesain yang digunakan dengan tepat dapat menurunkan risiko kegagalan pemasaran secara berarti. Perilaku konsumen yang mempengaruhi indikator dari profitabilitas usaha yaitu investasi usaha berdasarkan data statistik yang diperoleh dari hasil penelitian hanya motivasi yang menunjukkan tingkat signifikan pada taraf nyata 0.1 dengan tingkat kepercayaan $99 \%$, sedangkan persepsi, gaya hidup dan kelas social menunjukkan ketidak signifikanannya terhadap indikator profitabilitas usaha, namun pada dasarnya dari hasil penelitian ini dapat diambil beberapa kesimpulan sebagai berikut: Terdapat pengaruh positif (signifikan) dari perilaku konsumen sebagai indevenden variabel secara individu terhadap jumlah penjualan ikan patina sap di kab, Bogor keempat indikator tersebut saling menunjang dan terkait erat dalam mempengaruhi profitabilitas pejualan ikan patin asap di kab. Bogor
\end{abstract}

Kata kunci : pemasaran, patin asap, konsumsi produk 
PENDAHULUAN

\section{Latar Belakang}

Informasi yang terkini sangat dibutuhkan oleh perusahaan maupun konsumen tidak hanya untuk menghindari kesalahan pembuatan keputusan yang fatal tetapi juga sebagai sarana untuk menemukan peluangpeluang bisnis yang perlu digali lebih dalam oleh armada pemasaran.

Gambaran tentang konsumen yang sering mengubah - ubah keinginan dan implikasi-implikasi penting dalam keputusan pemasaran. Dewasa ini lingkungan pemasaran disadari atau tidak oleh pelaku pasar/bisnis cendrung berubah lebih cepat dan kompleks dibandingkan beberapa dasawarsa sebelumnya. Kondisi ini bisa dipahami karena dunia bisnis selalu berubah secara dinamis sehingga pemasar perlu berada dalam jarak yang dekat dengan konsumen dan mengetahui tingkah laku konsumen yang dilayani. Keadaan ini juga dimotori oleh adanya globalisasi perdagangan dan perkembangan teknologi yang menjadi faktor gerak. Faktor ini membuat perilaku konsumen dalam mengkonsumsi barang kebutuhan sehari-hari semakin cenderung bervariasi dan berubah dengan cepat. Konsumen dapat dengan mudah beralih ke sumber protein yang diinginkan karena tawaran produk yang semakin banyak, yang tidak hanya berasal dari suatu sumber protein hewani yang bersaing dalam segi harga, kualitas dan kuantitas.

Konsumen dengan leluasa dapat memilih produk-produk baru yang menawarkan kelebihan atau nilai yang dianggap sesuai dengan kebutuhan konsumen.
Lebih jauh, kondisi ini sangat ditunjang oleh ketersedian informasi produk yang luas sehingga konsumen dengan mudah dan cepat mengakses informasi tentang spesifikasi produk ataupun harga. Ini mengakibatkan tuntutan konsumen terhadap produk semakin kompleks sehinga produk yang tidak sesuai dengan harapan konsumen akan ditinggalkan.

Dihadapkan pada kondisi seperti ini, perusahaan (pemasar) harus semakin menyadari bahwa orientasi pada konsumen dan persaingan produk sangat dibutuhkan agar sukses dalam memasarkan produk. Manajer perlu memiliki kemampuan untuk melihat lebih dulu sebelum melangkah atau “look before you leap” . Manajer tidak cukup hanya mengandalkan intuisi bisnisnya dalam meliahat perilaku konsumen, persaingan, dan kekuatan lingkungan luar lainnya karena tuntutan yang semakin kompleks dan beragam dari masing - masing faktor tersebut. Manajer memerlukan pendekatan yang sistematik, obyektif dan logis untuk memberi pedoman atau arah bagi pengambil keputusan menjual

Adapun elemen yang sangat penting dimiliki bagi setiap pemasar (manajer pemasaran) dewasa ini untuk mampu melihat sebelum melangkah adalah informasi. Karena informasi memberikan gambaran yang lebih jelas bagi pemasar (manajer pemasaran) dalam berhubungan dengan konsumen dan mengantisifasi persaingan. Kebutuhan akan informasi dalam perusahaan atau pengusaha dapat dipenuhi jika menjalankan kegiatan yang disebut penelitian pemasaran salah satunya yaitu perilaku konsumen (consument behavior). 


\section{Rumusan Masalah}

Penetapan/ rumusan masalah merupakan langkah pertama dan terpenting yang harus dilakukan dalam riset pemasaran.

Rumusan masalah sangat penting karena kesalahan dalam merumuskan masalah akan mengakibatkan kosekuensi negatif seperti penentuan desain riset yang tidak tepat, pengambilan sampel yang salah, dan pengumpulaan data yang tidak relevan, yang pada akhirnya memberikan hasil riset yang tidak berdaya guna dalam pengambilan keputusan manajemen, bahkan temuannya bisa menyesatkan. Berkaitan dengan penetapan/perumusan masalah perlu dicermati adanya perbedaan pandangan antara masalaha manajemen dan riset pemasaran.

Adapun permasalahan/isu yang ada dilapangan saat ini;

- Konsumen cenderung lebih sedikit membeli ikan patin asap bila ke super market dan lebih banyak berbelanja dipasar tradisional.

- Bagaimana kebiasaan konsumen membeli/mengkonsumso ikan patin asap.

- Bagaimana perubahan sosial dan kondisi ekonomi serta usaha akan berpengaruh terhadap daya beli konsumen.

\section{Tujuan dan Manfaat}

Penelitian pamasaran yang berfokus pada motivasi konsumen membeli/mengkonsumsi ikan pating asap merupakan bagian atau fungsi yang keberadaannya semakin dibutuhkan untuk membantu kita dalam pembuatan keputusan komoditi yang kita usahakan dan arah pemasaran produk yang dihasilkan.
Mengkaji pengaruh motivasi konsumen secara individu terhadap daya beli dan konsumsi ikan patina sap di kabupaten Bogor

Sedangkan manfaat dari penelitian ini adalah ada dua titik pandang yaitu;

Aspek teori; sebagai salah satu sumber informasi tentang pengaruh motivasi konsumen terhadap volume penjualan ikan patin asap yang pada akhirnya akan diketahui volume produksi yang ditargetkan dan dapat mengembangkan strategi pemasaran untuk mencapai keuntungan yang optimal bagi pengusaha.

Aspek Praktis; sebagai pedoman pengambilan keputusan bagi pihak pengolah ikan patin asap untuk menambah persedian dalam menyiasati keinginan konsumen sehingga kepuasan konsumen saat membutuhkan ikan patin asap dapat terpenuhi dan dapat membuat strategi pemasaran ikan patin asap yang lebih memungkinkan untuk meningkatkan keuntungan perusahaan.

\section{Lembaga dan Saluran Pemasaran}

Untuk menyalurkan barang/jasa dari produsen ke konsumen, peranan lembaga perantara diharapkan dapat memperlancar arus barang/jasa tersebut. Lenbaga perantara ini dapat berbentuk fungsi pertukaran, fisik dan fungsi fasilitasn(Hague P dkk, 1986).

Saluran pemasaran adalah saluran yang digunakan untuk menyaluran produk/barang kepada konsumen. Menurut Wirodiharjo,(1964). ada beberapa faktor pentig yang harus dipertimbangkan jika memilih pola saluran pemasran yaitu;

1. Jarak antara produsen dan konsumen, makin jauh jarak antara produsen dan konsumen biasanya makin panjang 
saluran pemasaran yang dtempuh oleh produk tersebut.

2. Pertimbangan barang, yang meliputi nilai barang per unit, persatuan beratnya barang, tingkat kerusakan dan sifat teknis barang

3. Skala produksi, bila produksi berlangsung dalam ukuran kecil maka jumlah poduk yang dihasilkan berukuran kecil, hal mana akan tidak menguntungkan bila produsen langsung menjualnya ke pasar.

4. Posisi keuangan produsen, produsen yang posisi keuangannya kuat cenderung untuk memperpendek rantai tataniaga, sedangkan bila posisi keuangannya lemah maka saluran tataniaga berjalan relatif normal.

\section{Marjin Pemasaran}

Marjin Pemasaran adalah suatu istilah yang digunakan untuk menyatakan perbedaan harga yang dibayarkan kepada penjual pertama dan harga yang dibayar oleh pembeli terakhir. Dalam perusahaan marjin pemasaran merupakan sejumlah uang trtentu secara internal akunting, yang diperlukan untuk menutupi biaya dan laba, dan ini merupakan perbedaan antara harga pembelian dan harga penjualan (Prawirokusumo, 1990).

Marjin tataniaga dapat juga dinyatakan sebagai nilai dari jasa-jasa pelaksanaan kegiatan tataniaga, mulai dari tingkat produsen sampai ketingkat konsumen (Abbott, 1958).

Perbedaan pola rantai tataniaga dan perlakuan dari lembaga dalam sejumlah saluran tataniaga menyebabkan perbedaan harga jual. Semakin banyak lembaga perantara terlibat dalam penyaluran barang/jasa, maka semakin banyak perbedaan harga yang harus dibayar oleh konsummen dengan harga yang diterima produsen, karena setiap lembaga perantara yang terlibat dalam system tataniaga pada dasarnya mempunyai tujuan untuk memperoleh keuntungan.

Komponen marjin tataniaga meliputi biaya pemasara dan keuntungan lembaga perantara. Biaya pemasaran adalah biaya yang dikeluarkan untuk menyampaikan barang/jasa mulai dari produsen sampai pada konsumen. Sedangkan keuntungan merupakan penerimaan dari investasi akibat memperhitungkan opportunity cost-nya (Nitisemito,1981).

Biaya pemasaran, marjin tataniaga dan keuntungan lembaga pemasaran berbeda pada setiap jenis barang maupun tingkat lembaga pemasaran pada waktu yang berbeda pula. Marjin pemasaran umumnya dianalisis pada barang yang sama dan jumlah yang sama serta struktur pemasaran yang bersaing sempurna. Marjin pemasaran banyak digunakan dalam analisis efisiensi pemasaran (Abbott, 1958).

Bila keterlibatan tinggi, ada motivasi untuk memperoleh dan mengolah informasi dan kemungkinan yang jauh lebih besar dari pemecahan masalah yang diperluas. Terdapat dua jenis keterlibatan: (1) langgeng (ada sepanjang waktu karena peningkatan konsep diri) dan (2) situasional (keterlibatan sementara yang distimulasikan oleh risiko yang disadari, tekanan konformitas, atau pertimbangan lain). (Hersey and Blanchard, 1985).

Menurut Zanden 1984, Strategi terpenting adalah menerima motivasi ini sebagaimana adanya dan menemukan cara untuk menyajikan produk atau jasa sebagai sarana yang absah dari 
pemuasan motif. Klasifikasi kebutuhan selalu merupakan tantangan, dan kita menggunakan sembilan kategori;

1. Fisiologis - kebutuhan jasmaniah yang mendasar.

2. Keamanan - perhatian di atas kelangsungan hidup.

3. Afiliasi dan rasa memiliki - cinta dan penerimaan oleh orang lain.

4. Prestasi - keinginan untuk berhasil dalam pencapaian tujuan.

5. Kekuasaan - pemerolehan kendali atas nasib sendiri dan juga nasib orang lain.

6. Ekspresi diri - kebebasan dalam mengekspresikan keunikan diri sendiri.

7. Urutan dan pengertian - keinginan untuk mengetahui dan mengerti.

8. Pencarian variasi - perilaku menjajaki yang dilakukan untuk mempertahankan keadaan gairah yang diinginkan.

9. Atribusi sebab akibat - estimasi atau atribusi sebab akibat dari kejadian atau tindakan.

Bagaimana mengidentifikasi kebutuhan melalui penelitian dan kemudian memanfaatkan contoh tersebut melalui pemakaian bauran pemasaaran secara cakap.

Pengetahuan konsumen terdiri dari informasi yang disimpan di dalam ingatan. Pemasar khususnya tertarik untuk mengerti pengetahuan konsumen. Informasi dipegang oleh konsumen mengenai produk akan sangat mempengaruhi pola pembelian mereka. Analisis kesadaran dan citra sangat berguna untuk menjajaki sifat pengetahauan produk. Pemasar juga harus mempertimbangkan pengetahuan pembelian berkenaan dengan kepercayaan yang dipegang oleh konsumen mengenai di mana dan kapan pembelian harus terjadi.

$$
\text { Pengetahuan pemakai adalah }
$$
bidang sisi lain yang harus dipertimbangkan. Perluasan pengetahuan seperti ini dapat menjadi jalan yang berarti untuk meningkatkan penjualan. (Sadli.1973).

Pertimbangan diberikan pada metode alternatif untuk pengukuran pengetahuan. Pengalaman pembelian atau pemakaian, walaupun berhubungan dengan pengetahuan, tidak selalu memberikan indikasi yang akurat mengenai berapa banyak persisnya informasi yang dimiliki konsumen. Pengukuran pengetahuan objektif berusaha menilai isi ingatan yang aktual. Sebaliknya, pengukuran pengetahuan subjektif meminta orang untuk menunjukkan berapa banyak pengetahuan yang mereka rasa mereka miliki (Slamet, 2003). .

Suatu analisis mengenai sikap konsumen dapat menghasilkan manfaat diagnostik maupun prediktif. Mengidentifikasi pangsa pasar yang respektif, mengevaluasi kegiatan pemasaran pemasaran yang sekarang dan yang potensial, dan perilaku manusia (konsumen) masa datang adalah sebagian dari cara-cara utama dimana sikap dapat membantu pengambilan keputusan pemasaran (Wahjosumidjo,1987).

Sikap didefinisikan sebagai evaluasi menyeluruh. Intensitas, dukungan, dan kepercayaan adalah sifat penting dari sikap. Masing-masing sikap ini akan bergantung pada sejumlah faktor. Hubungan sikap-perilaku seharus bertumbuh lebih kuat bila pengukuran sikap menetapkan secara benar komponen tindakan, target, waktu, 
dan konteks, (2) interval waktu antara pengukuran sikap dan perilaku menjadi lebih singkat, (3) sikap didasarkan pada pengalaman langsung, dan (4) perilaku menjadi kurang

satu ancangan untuk memeriksa basis bagi sikap produk yang dimiliki konsumen berkenaan dengan atribut produk adalah model sikap multiatribut. Baik model Fishbein maupun model angka-ideal memberikan informasi mengenai presepsi konsumen terhadap produk yang sudah ada, tetapi hanya yang belakangan yang mengidentifikasi konfigurasi pilihan atau ideal dari konsumen mengenai atribut produk. Sebaliknya, memungkinkan estimasi dampak relatif dari sikap dan pengaruh sosial pada maksud perilaku (Slamet M, 2003).

$$
\text { Keputusan pembelian }
$$

bervariasi antar individu karena karateristik unik yang dimiliki masingmasing individu. Kepribadian didefinisikan sebagi respon yang konsisten terhadap stimulus lingkungan. Tiga (3) teori atau acangan terhadap studi kepribadian mencakupi psikoanalisis, sosio-psikologis, dan faktor ciri. Ancangan yang lebih baru terhadap pemakai kepribadian mencakupi kepribadian merek dan yang lebih baru lagi berusaha menghubungkan kepribadian dengan elemen pengambilan keputusan konsumen dan pengolahan informasi, seperti kebutuhan akan kognisi. Nilai kepribadian juga menjelaskan perbedaan individu diantara konsumen.

External Variables: Culture

Family

Orther Reeference Groups

Social Class
Riset, mengidentifikasikan nilainilain seperti terminal dan instrumen, atau tujuan ke mana perilaku diarahkan dan sarana pencapaian tujuan itu. Ancangan yang memberi harapan, yaitu menghubungkan nilai dengan atribut produk, disebut penjenjangan dan tampaknya berguna dalam memangsa pasar dan pengembangan produk serta strategi komunikasi untuk menjangkau pasar (Hanafi, 1986).

Orang mengembangkan konsepsi yang digunakakn untu menafsirkan, meramal kan, dan mengendalikan lingkungan mereka. Konsepsi atau pola ini menghasilkan pola perilaku dan struktur sikap yang meminimumkan ketidakcocokan dan ketidak- konsistenan di dalam kehidupan seseorang. Psikografi atau AIO mengukur bentuk operasional dari gaya hidup. AIO adalah singkatan dari Activities (kegiatan), interest (minat), dan opinion (opini), dan mungkin bersifat umum atau spesifik produk (Arnold dkk. 1986).

Pemecahan praktis bagi masalah bauran pemasaran kerap mengharuskan kita memandang pengukuran ganda terhadap karakteristik individu. Selain kepribadian dan gaya hidup, pengukuran seperti ini mencakupi sumber daya ekonomi seperti uang dan waktu, dan juga pengukuran demograpi seperti usia atau sifat rumah tangga. Semua variabel ini memungkinkan berinteraksi dengan situasi pemakaian untuk produk bersangkutan ( Kotler and Gary Astrong, 1994). 
Internal Variables:

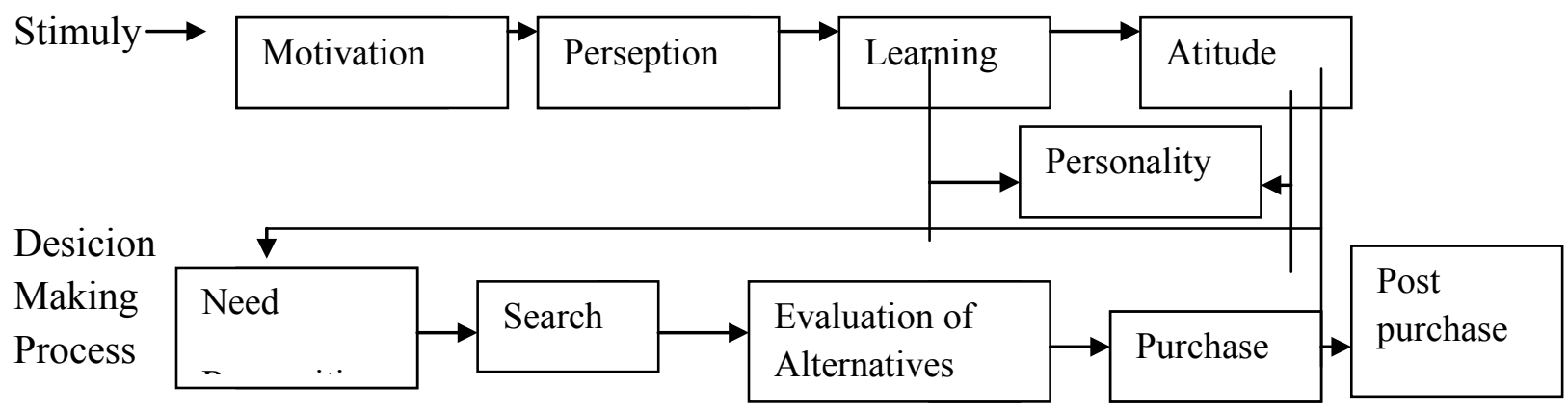

Gambar 1. Consumen behavior Model

Sumber : Engel, 1995.

\section{METODE PENELITIAN}

\section{Waktu dan Tempat}

Penelitian ini dilakukan di Kabupaten Bogor, pada bulan Juni September 2013.

\section{Metodologi}

Metode yang digunakan dalam penelitian ini adalah metode survey pada sentra pemsaran ikan awetan yaitu Kabupaten Bogor.Untuk pengambilan data primer diperoleh dari hasil survey ke pasar ikan awetan langsung, observasi lapang dan wawancara langsung dengan menggunakan kuesioner. Sedangkan data skunder diambil melalui data yang tersedia pada instansi terkait.

\section{Analisis Data}

Data primer dan skunder dianalisis untuk mengetahui kegiatan serta fungsifungsi pemasaran. Analisis narjin tataniaga dalam penelitian ini dilakukan dengan cara menghitung marjin tataniaga dan penyebarannya pada setiap lembaga perantara yang terlibat pada sistem pemasaran yang dilakukan. Untuk menganalisa harga pokok, data yang dikumpulkan dari pengolah ikan patin asap/responden dan petugas yang terkait, lalu diolah dan disajikan dalam bentuk tabulasi.

\section{Analisis Mata rantai Tata niaga}

Analisis mata rantai tataniaga dilakukan untuk mengetahui berbagai saluran tataniaga yang dilakukan dalam memasarkan ikan patin asap, mulai dari produsen sampai pada konsumen.

\section{Analisis Harga Pokok}

Harga pokok produksi dihitung berdasarkan besar-kecilnya biaya yang dikeluarkan dan hasil produk rielnya. Harga pokok produksi dihitung:

HPP $=\frac{\text { Biaya Tetap Total }+ \text { Biaya Variable Total }}{\text { Jumlah Produksi Ril }}$

\section{Analisis Marjin Tataniaga}

Analisis marjin tataniaga digunakan untuk melihat tingkat efisiensi operasional pemasaran ikan patin asap, Marjin tataniaga dihitung berdasarkan pengurangan harga penjualan dengan harga pembelian pada setiap tingkat lembaga perantara. Untuk mengetahui berapa besar penerimaan yang akan diterima dari setiap rupiah yang dikeluarkan oleh masing-masing lembaga perantara dalam kegiatan pemasaran ikan patin asap dapat dilihat dari ratio penerimaan terhadap biaya, perhitungannya dilakukan dengan rumus (Limbong dan Sitorus, 1987):

$\mathrm{Msi}=\mathrm{Psi}-\mathrm{Pbi}$ 
$\mathrm{Msi}=\mathrm{Ci}+\mathrm{Bi}$

(2),

dimana;

Msi : marjin tataniaga pada tingkat i,

Psi : harga jual pada tingkat $i$,

Pbi : harga beli pada tingkat i,

$\mathrm{Ci}$ : biaya pemasaran pada tingkat $\mathrm{i}$,

$\mathrm{Bi}$ : keuntungan hasil pemasaran pada tingkat $i$,

Ratio terhadap biaya dapat digunakan untuk mengukur tingkat keuntungan relative dari kegiatan pemasaran ikan patin asap tersebut. Artinya dari angka rasio penerimaan terhadap biaya tersebut dapat diketahui apakah mata rantai tataniaga ikan patin asap dapat menguntungkan atau tidak. Suatu pola pemasaran dikatakan menguntungkan jika nilai ratio lebih besar dari satu (1), dan mengalami kerugian jika nilai ratio lebih kecil dari satu (1). Untuk mengetahui berapa besar penerimaan yang akan didapat dari setiap rupiah yang dikeluarkan oleh masing-masing lembaga perantara dalam kegiatan pemasaran ikan patin asap dapat dilihat dari ratio penerimaan terhadap biaya, perhitungan dilakukan dengan rumus (Suharjo dan Patong, 1973): R/C ...(3) dimana;

$\mathrm{R}$ (revenue) : pendapatan $\mathrm{C}$ (cost) : pengeluaran/biaya Mata rantai tataniaga 1.

Produsen (pengolah) $\rightarrow$ Pedagang pengumpul desa $\rightarrow$ Pedagang pengumpul Kecamatan $\rightarrow$ pedagang Pengecer $\rightarrow$ Konsumen.

2. Mata rantai tataniaga 2.

Produsen (pengolah) $\rightarrow$ Pedagang pengumpul Kecamatan $\rightarrow$ Pedagang Pengecer $\rightarrow$ Konsumen

Gambar 2. Mata rantai tataniaga ikan patin asap di Kabupaten Bogor

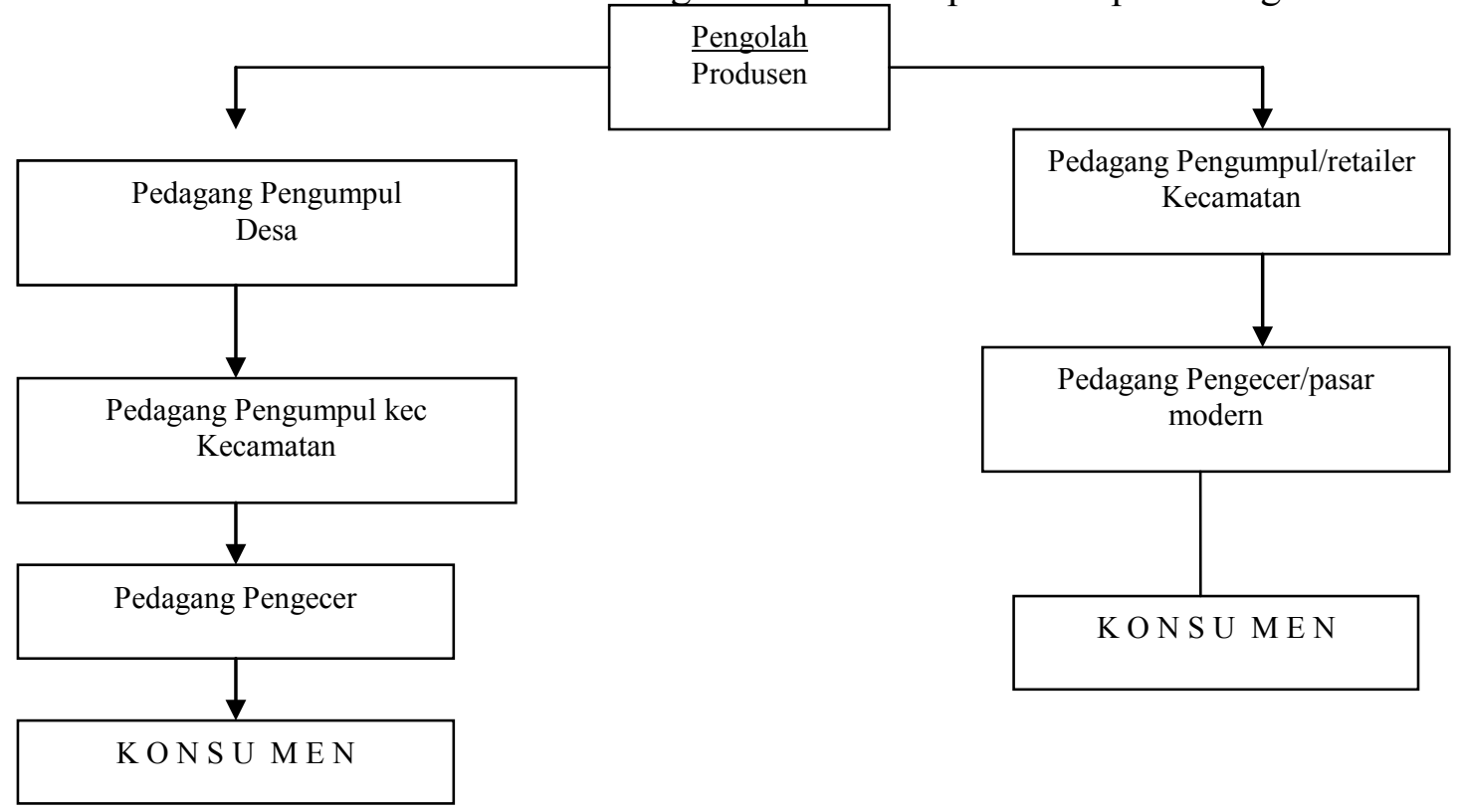

Gambar 3. Mata Rantai tataniaga ikan patin asap di Kabupaten Bogor.

Keterangan :M.R.P. 1 . Pengumpul Kecamatan

M.R.P. 2. Pengecer pasar 


\section{METODOLOGI}

\section{Populasi dan Sampel}

Populasi yang diharapkan adalah seluruh konsumen yang datang untuk membeli ikan patina asap pada pasar tradisional khususnya, banyak sampel yang diambil 60-100 sampel dan dilakukan selama waktu penelitian berjalan.

\section{Teknik dan Alat Pengumpul data}

\section{Sumber Data}

Sumber data dalam penelitian ini meliputi:

Data primer, merupakan data yang diperoleh dari sumbernya, baik individu atau perorangan. Dalam penelitian ini bentuk hasil pengisisan kuesioner oleh responden (konsumen).

Data skunder, merupakan data yang diperoleh dari literatur, buku-buku ilmiah yang didapatkan dari studi literatur diperpustakaan kampus dan book store.

\section{Teknik Pengumpulan Data}

Teknik pengumpulan data penelitian ini menggunakan wawancara, kuesioner (angket), studi pustaka dan dokumentasi.

\section{Alat Pengumpul data}

Skala penelitian yang digunakan adalah skala rasio dimana memiliki urutan interval yang sama di antara titik titik yang berdekatan.

Dimana sample yang akan diambil sebanyak $60-100$ konsumen sebagai responden pasar tradisonal di Kabupaten Bogor dan metode random sampling. Dengan menggunakan kuesioner terstruktur dan terbuka.

\section{Teknik Pengolahan dan Analisis Data}

\section{Penentuan Sampel}

Untuk mendapatkan sampel reprensentatif dalam penelitian ini digunakan stratified random sampling yaitu metode penelitian sampel dengan membagi populasi ke dalam kelompokkelompok yang homogen, yang kemudian sampel diambil secara acak. Jumlah sampel dapat dicari dengan rumus (Sugiarto, 2001);

$$
\mathrm{N}=\frac{\left[\frac{\mathrm{Za}}{2}\right] \cdot \mathrm{p} \cdot \mathrm{q}}{\mathrm{e} 2}
$$

Keterangan :

$\mathrm{N}=$ Jumlah sampel minimum

$\mathrm{Z}=$ Nilai distribusi normal

$\mathrm{e}=$ Toleransi

$\mathrm{p}=$ Prosentase kuesioner dijawab benar

$\mathrm{q}=$ Prosentase kuesioner dijawab salah

\section{Desain Penelitian adalah penelitian kuantitatif.}

Penelitian kuantitatif. dimana hasil penelitian menggambarkan pengaruh perilaku konsumen dan bauran pemasaran terhadap penjualan ikan patin asap pada pasar tradisional Kabupaten Bogor, hasil akhir terlihat jumlah konsumen yang memanfaatkan pasar ikan/ suplier ikan untuk memenuhi kebutuhan ikan air tawar dan dapat menentukan strategi pemasaran ikan air tawar di masa depan.

Dimana jenis data yang dikumpulkan/diperoleh merupakan data primer yang diperoleh dari wawancara langsung dan penyebaran kuesioner, dengan metode pengumpulan data survei. 
Teknik Analisis Data

Karakteristik Internal Perilaku

Konsumen

Perilaku konsumen memiliki kepentingan khusus bagi orang yang, karena pelbagai alasan, berhasrat mempengaruhi atau mengubah perilaku tersebut, termasuk mereka yang kepentingan utamanya adalah pemasaran, pendidikan dan perlindungan konsumen, serta kebijakan umum.

Elemen kunci dalam definisi ini adalah pertukaran antara pelanggan dan penyuplai. Masing-masing pihak memberikan sesuatu yang bernilai kepada pihak lain dengan tujuan memenuhi kebutuhan mereka masingmasing. Dalam sektor swasta atau publik, dalam perusahaan besar atau kecil, dalam pengamatan bahwa hanya ada dua cara untuk menciptakan dan mempertahankan prestasi unggul dalam waktu yang lama. Pertama, beri perhatian luar biasa kepeda pelanggan anda... lewat pelayanan yang unggul dan kualitas yang unggul. Kedua, teruslah berinovasi.

Perilaku konsumen, biasanya, penuh arti dan berorientasi tujuan. Produk dan jasa yang diterima atau ditolak berdasarkan sejauh mana keduanya dipandang relevan dengan kebutuhan dan gaya hidup. Karene individupun sanggup sepenuhnya mengabaikan semua yang dikatakan pemasaran. Mengerti dan mengadaptasi motivasi dan perilaku konsumen bukanlah pilihan - keduanya adalah kebutuhan mutlak untuk kelangsungan hidup kompetitif. Dalam analisis akhir, konsumen memegang kendali, dan pemasar berhasil bila produk atau jasanya dipandang menwarkan mafaat yang riil. Perilaku konsumen adalah suatu proses, dan pembelian hanyalah satu tahap. Banyak pengaruh yang mendasari, berjajar dari motivasi internal hingga pengaruh sosial dari pelbagai jenis.

Namun perilaku konsumen dapat dimengerti,walau tidak sempurna, melalui penelitian, tetapi usaha yang didesain dan digunakan dengan tepat dapat menurunkan risiko kegagalan pemasaran secara berarti. Kedaulatan konsumen menyajikan tantangan yang berat, tetapi pemasaran yang terampil dapat mempengaruhi perilaku bila produk atau jasa yang ditawarkan didesain untuk memenuhi kebutuhan pelanggan. Keberhasilan penjuaaalan terjadi karena permintaan memang sudah ada atau masih laten dan menunggu aktivasi oleh tawaran pemasaran yang tepat, dimana relevansi konsumen adalah masalah sentralnya.

Faktor internal perilaku konsumen yang diduga berhubungan dengan faktor yang berpengaruh langsung dengan profitabilitas usaha yaitu: motivasi, persepsi, gaya hidup dan kelas sosial yang dapat dilihat pada Tabel 1. 
Tabel 1. Sebaran Internal Perilaku Konsumen (X1)

\begin{tabular}{|l|l|l|c|c|}
\hline No. & \multicolumn{1}{|c|}{ Perilaku konsumen } & \multicolumn{1}{|c|}{ Kategori } & P & Persentase \\
\hline 1 & Motivasi & Tinggi $(>25)$ & 17 & $21.25 \%$ \\
\hline & & Sedang $(=24)$ & 23 & $28.75 \%$ \\
\hline & & Rendah $(<23)$ & 40 & $50 \%$ \\
\hline 2. & Persepsi & Tinggi $(>33.33)$ & 30 & $37.50 \%$ \\
\hline & & Sedang $(30-33)$ & 40 & $50 \%$ \\
\hline 3. & Gaya Hidup & Rendah (<29.67) & 10 & $12.50 \%$ \\
\hline & & Tinggi (>24.67) & 43 & $53.75 \%$ \\
\hline & & Sedang $(23-24)$ & 21 & $26.25 \%$ \\
\hline 4. & Kelas Sosial & Rendah (<22.33) & 16 & $20 \%$ \\
\hline & & Tinggi (>26.33) & 42 & $52,50 \%$ \\
\hline & & Sedang $(23-26)$ & 34 & $42,50 \%$ \\
\hline
\end{tabular}

Sumber: diolah Juni-September 2013

Tabel 1. diatas menunjukkan bahwa motivasi konsumen yang menggunakan jasa pasar tradisional untuk membeli ikan patin asap dengan persentase $(21.25 \%)$ pada kategori tinggi, $(28.75 \%)$ pada kategori sedang dan (50 \%) pada kategori rendah. Motivasi adalah dorongan keinginan yang timbul dari diri konsumen akibat pengauruh dari luar dirinya. Hal ini menunjukkan motivasi konsumen untuk melakukan kegiatan penjualan ikan patin asap dan rasa keinginan untuk berusaha tinggi, dan dengan motivasi tersebut konsumen bisa mempersepsikan kegiatan usaha yang saat ini berjalan, dapat meningkatkan profitabilitas usaha.

Kebutuhan adalah variabel utama dalam motivasi. Kebutuhan sebagai perbedaan yang disadari antara keadaan ideal dan keadaan sebenarnya, yang memadai untuk mengaktifkan perilaku. Bila kebutuhan diaktifkan, hal ini menimbulkan dorongan (perilaku yang diberi tenaga), yang disalurkan kearah tujuan tertentu yang sudah dipelajari sebagai insentif. Keterlibatan (relevansi yang disadari atau kecocokan) adalah faktaor penting dalam mengerti motivasi. Keterlibatan mengacu pada tingkat relevansi yang disadari dalam tindakan pembelian dan konsumsi. Bila keterlibatan tinggi, ada motivasi untuk memperoleh dan mengolah informasi dan kemungkinan yang jauh lebih besar dari pemecahan masalah yang diperluas.

Terdapat dua (2) jenis keterlibatan: (1) langgeng (ada sepanjang waktu karena peningkatan konsep diri) dan (2) situasional (keterlibatan sementara yang distimulasikan oleh risiko yang disadari, tekanan konformitas, atau pertimbangan lain). Strategi terpenting adalah menerima motivasi ini sebagaimana adanya dan menemukan cara untuk menyajikan produk atau jasa sebagai sarana yang absah dari pemuasan motif. Persepsi adalah proses kognitif yang dialami oleh konsumen di dalam memahami informasi tentang lingkungannya, baik lewat penglihatan, pendengaran, penghayatan, perasaan dan penciuman.

Kunci dari persepsi adalah terletak pada pengenalan bahwa persepsi itu merupakan suatu penafsiran yang unik 
terhadap situasi, dan bukannya suatu pencatatan yang benar terhadap situasi. Persepsi konsumen ikan air tawar terhadap profitabilitas usaha adalah sejauhmana konsumen memahami tentang produk yang diinginkannya.

Sebagaimana telah disinggung di bab terdahulu, bahwa persepsi sebagai suatu proses pengorganisasian dan penafsiran kesan dan makna seseorang (konsumen) atas lingkungannya. Persepsi konsumen merupakan hal penting, karena persepsi berhubungan dengan perilaku konsumen, yang mana sangat berpengaruh terhadap keputusan konsumen untuk menentukan sesuatu yang dibutuhkan. Sehingga secara langsung dapat mempenguruhi volume penjualan harian dan mingguan maupun bulanan pasar tradisional sebagai penyedia produk, dan berpengaruh langsung terhadap penjualan ikan patin asap. Gaya hidup adalah pola di mana orang hidup dan menghabiskan waktu serta uang. Gaya hidup adalah hasil dari jajaran total ekonomi budaya, dan kekuatan kehidupan sosial yang menyokong kualitas manusia seseorang. Orang mengembangkan konsepsi yang digunakakn untu menafsirkan, meramalkan, dan mengendalikan lingkungan mereka. Konsepsi atau pola ini menghasilkan pola perilaku dan struktur sikap yang meminimumkan ketidakcocokan dan ketidak- konsistenan di dalam kehidupan seseorang. Psikografi atau AIO mengukur bentuk operasional dari gaya hidup. AIO adalah singkatan dari Activities (kegiatan), interest (minat), dan opinion (opini), dan mungkin bersifat umum atau spesifik produk.

Persentasi gaya hidup konsumen ikan air tawar terhadap profitabitas usaha adalah: $53.75 \%$ pada kategori tinggi, $36.25 \%$ pada kategori sedang, dan pada kategori $20 \%$, hal ini menunjukan sebagian besar profitabilitas penjualan ikan patin asap dipengaruhi oleh gaya hidup konsumendi kab. Bogor. Dari hasil penelitian menunjukkan, bahwa gaya hidup konsumen ikan patin asap terhadap profitabilitas usaha mayoritas tergolong tinggi (50\%), kategori sedang $(26.25 \%)$ dan sisanya $(20 \%)$ termasuk yang kategori rendah. Hasil ini dapat disimpulkan bahwa secara umum gaya hidup konsumen terhadap profitabilitas usaha tergolong cukup tinggi (80\%), pada kategori sedang hingga tinggi. Kelas sosial merupakan pengelompokan orang yang relatif permanen dan homogen di dalam masyarakat, yang memungkinkan kelompok orang untuk membandingkan dengan kelompok lain.

Kelompok - kelompok ini memiliki posisi inferior atau superior oleh individu yang terdiri dari masyarakat bersangkutan, kerap didasarkan kepada posisi ekonomi di dalam pasar. Kelas sosial adalah Kelompok-kelompok yang terpisah dalam teori, tetapi dalam prakatek mereka biasanya dianalisis sebagai variabel status tanpa terputus. Status adalah konsep multidimensi dan paling baik diukur menurut konsep tersebut. Pekerjaan adalah ukuran tunggal terpenting dari kelas sosial individu. Variabel penting yang lain adalah interaksi pribadi seseorang dengan individu lain, barang milik (pemilikan), orientasi nilai, dan kesadaran kelas.

Kelas sosial secara tradisional di bagi ke dalam enam (6) kelompok : atas atas atas bawah, menengah atas, menengah bawah, bawah atas, dan bawah bawah atau kelas marginal. 
Sistem klasifikasi yang lebih baru menekankan kelas kapitalis atau profesional yang diperbesar di dalan kelas menengah atas atau bawah bawah. Namun, kelas sosial selalu dalam transisi sehingga menyebabkab status dan simbolnya menjadi dinamis. Masingmasing kelompok memperlihatkan nilai dan perilaku karakteristik yang berguna untuk analisis konsumen dalam mendesain program pemasaran. Adalah perlu untuk menganalisis pengenalan kebutuhan, proses pencarian, kriteria evaluasi, dan pola pembelian dari pelbagai kelas sosial untuk mencocokkan produk dan komunikasi secara benar dengan kelas sosial yang aktual dan yang dicita-citakan.

Persentasi kelas sosial konsumen ikan patin asap terhadap profitabitas usaha adalah: $52.50 \%$ pada kategori tinggi, $42.50 \%$ pada kategori sedang, dan pada kategori $5 \%$, hal ini menunjukan sebagian besar profitabilitas penjualan ikan patin asap dipengaruhi oleh kelas sosial konsumen khusus di kab. Bogor. Dari hasil penelitian menunjukkan, bahwa kelas sosial konsumen ikan patin asap terhadap profitabilitas usaha mayoritas tergolong tinggi (52.50\%), kategori sedang (42.50 $\%)$ dan sisanya $(5 \%)$ termasuk yang kategori rendah. Hasil ini dapat disimpulkan bahwa secara umum kelas sosial konsumen terhadap profitabilitas usaha tergolong cukup tinggi (95\%), pada kategori sedang hingga tinggi.
Sehingga secara garis besar perilaku konsumen yang diwakili oleh faktor faktor: motivasi, persepsi, gaya hidup dan kelas sosial untuk kesimpulan sementara berpengaruhi positip terhadap tingkat profitabilitas penjualan ikan patin asap, khususnya untuk konsumen kab. Bogor dan sekitarnya. Sehingga dapat dibahas seperti data diatas dan merupakan hasil penelitian yang dilakukan. Hubungan perilaku konsumen dengan Profitabilitas penjualan ikan patin asap. Hasil penelitian menunjukkan bahwa perilaku konsumen profitabilitas penjualan ikan patin asap mayoritas tergolong tinggi, dimana disetiap indicator menunjukkan kategori sedang hingga tinggi berkisar antara $(26.25 \%$ $53.75 \%)$ sedangkan kategori rendah berkisar antara $(5 \%-50 \%)$. Hasil ini dapat disimpulkan bahwa secara umum perilaku konsumen terhadap profitabilitas penjualan ikan patin asap tinggi yang rata -rata $(41.25 \%)$ bila dilihat dari kategori rendah rata - rata $(21.87 \%)$ dan yang sisanya ada pada kategori sedang.

Perilaku konsumen merupakan hal penting, karena perilaku berhubungan denga profitabilitas penjualan ikan patin asap. Tabel 2. juga menunjukkan, bahwa hubungan perilaku konsumen internal dengan profitabilitas usaha memperlihatkan pengaruh yang signifikan. 
Tabel 2. Koefisien Korelasi perilaku konsumen dengan profitabilitas penjualan ikan patin asap.

\begin{tabular}{|c|c|c|c|c|}
\hline \multirow{2}{*}{ No. } & \multirow{2}{*}{ Perilaku Konsumen (X1) } & \multicolumn{2}{|c|}{ Profitabilitas Usaha (Y) } & \\
\cline { 3 - 5 } & & Vol. Penjualan & Kesjh. Peg. & Inv. Usaha \\
\hline 1. & Motivasi & $0,256^{*}$ & -0.015 & $0.320^{* *}$ \\
\hline 2. & Persepsi & 0.181 & $0.530^{* *}$ & 0.010 \\
\hline 3. & Gaya Hidup & $0.455^{* *}$ & 0.009 & -0.022 \\
\hline 4. & Kelas Sosial & -0.071 & $0.241^{*}$ & 0.178 \\
\hline
\end{tabular}

* Signifikan pada taraf nyata 0.05

** Signifikan pada taraf nyata 0.1

Sumber: Data primer diolah Juni - September 2013

Secara statistik perilaku konsumen menunjukkan pengaruh yang berarti (nyata), dari beberapa indikator seperti; motivasi mempengaruhi volume penjualan dengan tingkat signifikan 0.05 dengan taraf nyata, dan gaya hidup sangat kuat mempengaruhi volume penjualan ditunjukkan pada tingkat signifikan 0.1 pada taraf nyata dengan tingkat kepercayaan $99.9 \%$, sedangkan perepsi dan kelas social menunjukkan tingkat tidak signifikan terhadap volume penjualan, sehingga bagaimana meningkat motivasi dan gaya hidup konsumen agar dapat meningkatkan volume penjualan ikan patin asap khusus di kabupaten Bogor.

Gaya hidup pun menunjukkan tidak signifikan terhadap kesejahteraan pegawai, tingkat signifikan pada taraf nyata 0.05 ditunjukkan oleh kelas sosial terhadap kesejahteraan pegawai hingga pada tingkat kepercayaan $95 \%$. Perilaku konsumen yang mempengaruhi indikator dari profitabilitas usaha yaitu investasi usaha berdasarkan data statistik yang diperoleh dari hasil penelitian hanya motivasi yang menunjukkan tingkat signifikan pada taraf nyata 0.1 dengan tingkat kepercayaan $99 \%$, sedanhkan persepsi, gaya hidup dan kelas social menunjukkan ketidak signifikanannya terhadap indikator profitabilitas usasah, namun pada dasarnya keempat indikator tersebut saling menunjang dan terkait erat dalam mempengaruhi profitabilitas penjualan ikan patin asap khususnya di kabupaten Bogor dengan signifikan pada taraf nyata $(0.05-0.1)$ atau pengaruh pada tingkat kepercayaan (95 $99 \%$ ) dan sangat berpengaruh nyata pada tingkat keuntungan usaha yang sedang berjalan, walau masih memungkinkan kiat-kiat baru untuk mempengaruhi perilaku konsumen agar tetap menggunakan jasa pasar untuk memenuhi kebutuhan ikan patin asap. Profitabilitas adalah hubungan antara pendapatan (income) terhadap investasi, yang sering disebut tingkat pengembalian terhadap investasi (rate of return on investment), juga dapat dipakai untuk menghitung penggunaan sumberdaya untuk mencapai sasaran tanpa menyianyiakan sumberdaya yang ada, sehingga diupayakan seefisien mungkin. Semakin tinggi hasilnya, menunjukkan semakin kaku (inflexible) operator usaha tersebut untuk menyesuaikan dengan cepat dan efisien terhadap kondisi perubahan. Semakin tinggi semakin efisien, pada umumnya dihitung bila usaha dilengkapi dengan laporan keuangan yang rapid an tertib, 
sehingga kekuatan dan kelemahna dana usaha dapat segera diperkirakan. Hal ini sangat penting untuk pengembangan atau mempertahankan usaha yang ada. Keberhasilan usaha harus di imbangi dengan pengelolaan dana yang baik sehingga pelaksanaan usaha dapat berjalan lancar. Karakteristlk Profitabilitas Usaha penjualan ikan patin asap yang dipengaruhi oleh factor factor internal dan eksternal perilaku konsumen di kabupaten Bogor.
Faktor eksternal dan internal yang mempengaruhi langsung terhadap profitabilitas usaha dalam kegiatan penelitian yaitu: bauran pemasaran $4 \mathrm{P}$ (produk, place, price and promosi), bauran pemasaran $3 \mathrm{P}$ (produk, place and price), bauran pemasaran $2 \mathrm{P}$ (produk and price), dan bauran pemasaran $2 \mathrm{P}$ ( place and promosi), juga motivasi, persepsi, gaya hidup serta kelas sosial tergambar pada Tabel. berikut ini.

Tabel 3. Sebaran Profitabilitas Usaha penjualan ikan patin asap (Y)

\begin{tabular}{|l|l|l|c|c|}
\hline No. & \multicolumn{1}{|c|}{$\begin{array}{c}\text { Profitabilitas Usaha } \\
\text { Penjualan }\end{array}$} & \multicolumn{1}{|c|}{ Kategori } & N & Persentase \\
\hline 1 & Volume Penjualan & Tinggi $(>25)$ & 24 & $30 \%$ \\
\hline & & Sedang $(=24)$ & 27 & $33.75 \%$ \\
\hline & & Rendah $(<23)$ & 29 & $36.25 \%$ \\
\hline 2. & Kesejahteraan Pegawai & Tinggi $(>25.33)$ & 42 & $52 \%$ \\
\hline & & Sedang $(22-25)$ & 34 & $42.50 \%$ \\
\hline & & Rendah $(<21.67)$ & 4 & $5.50 \%$ \\
\hline 3. & Investasi Usaha & Tinggi $(>17.67)$ & 23 & $28.75 \%$ \\
\hline & & Sedang $(=17)$ & 32 & $40 \%$ \\
\hline & & Rendah $(<16.33)$ & 25 & $31.25 \%$ \\
\hline
\end{tabular}

Sumber : diolah Juni - September 2013.

Volume penjualan ikan patin asap terhadap profitabitas usaha adalah: $30 \%$ pada kategori tinggi, pada kategori sedang $33.75 \%$, dan pada kategori rendah $36.25 \%$, hal ini menunjukan sebagian besar profitabilitas usaha ikan patina sap juga dipengaruhi oleh volume penjualan, khusus di kab. Bogor. Dari hasil penelitian menunjukkan, bahwa volume penjualan ikan patin asap terhadap profitabilitas usaha mayoritas tergolong tinggi (30\%) kategori sedang $(33.75 \%)$ dan sisanya (36.75 \%) termasuk yang kategori rendah. Hasil ini dapat disimpulkan bahwa secara umum volume penjualan terhadap profitabilitas usaha tergolong cukup tinggi (63.75\%), pada kategori sedang hingga tinggi.
Hasil ini dapat disimpulkan bahwa secara umum kesejahteraan terhadap profitabilitas usaha tergolong cukup tinggi (94.50\%), pada kategori sedang hingga tinggi. Dari hasil penelitian menunjukkan, bahwa investasi usaha ikan air tawar terhadap profitabilitas usaha mayoritas tergolong rendah(23.75 \%) kategori tinggi, (40 \%) kategori sedang dan sisanya $(36.75 \%)$ termasuk yang kategori rendah. Hasil ini dapat disimpulkan bahwa secara umum investasi usaha terhadap profitabilitas usaha tergolong cukup tinggi (63.75\%), pada kategori sedang hingga tinggi.

Profitabilitas usaha merupakan hal penting, karena berhubungan dengan kelanggengan atau perputaran usaha 
ikan patin asap. Tabel 12. juga memperlihatkan pengaruh yang menunjukkan, bahwa hubungan signifikan terhadap indicator yang indikator internal (volume penjualan, mempengaruhinya seperti perilaku kesejahteraan pegawai dan investasi konsumen. usaha) dengan profitabilitas usaha

Tabel 4. Koefisien Korelasi Perilaku Konsumen dengan profitabilitas usaha ikan patin asap.

\begin{tabular}{|l|l|l|l|l|}
\hline \multirow{2}{*}{ No } & \multirow{2}{*}{ Perilaku Konsumen (X1) } & \multicolumn{3}{|c|}{ Profitabilitas Usaha (Y) } \\
\cline { 3 - 5 } & & Vol. Penjualan & \multicolumn{1}{|c|}{ Kesjh. Peg. } & Inv. Usaha \\
\hline 1. & Motivasi & $0,256^{*}$ & -0.015 & $0.320^{* *}$ \\
\hline 2. & Persepsi & 0.181 & $0.530^{* *}$ & 0.010 \\
\hline 3. & Gaya Hidup & $0.455^{* *}$ & 0.009 & -0.022 \\
\hline 4. & Kelas Sosial & -0.071 & $0.241^{*}$ & 0.178 \\
\hline
\end{tabular}

* Signifikan pada taraf nyata 0.05

** Signifikan pada taraf nyata 0.1

Sumber: Data primer diolah Juni - Sptember 2013.

Secara statistik profitabilitas usaha menunjukkan pengaruh yang berarti (nyata), dari beberapa indikatornya seperti; volume penjualan dipengaruhi motivasi pada tingkat signifikan 0.05 dengan taraf nyata, dan investasi usaha sangat kuat dipengaruhi motivasi ditunjukkan pada tingkat signifikan 0.1 pada taraf nyata dengan tingkat kepercayaan $99.9 \%$, sedangkan kesejahteraan pegawai menunjukkan tingkat tidak signifikan terhadap motivasi, sehingga bagaimana meningkatkan profitabilitas usaha agar dapat meningkatkan motivasi konsumen ikan patina sap di kab. Bogor. Perilaku konsumen yang mempengaruhi indikator dari profitabilitas usaha yaitu investasi usaha berdasarkan data statistik yang diperoleh dari hasil penelitian hanya motivasi yang menunjukkan tingkat signifikan pada taraf nyata 0.1 dengan tingkat kepercayaan $99 \%$, sedanhkan persepsi, gaya hidup dan kelas social menunjukkan ketidak signifikanannya terhadap indikator profitabilitas usaha, namun pada dasarnya keempat indikator tersebut saling menunjang dan terkait erat dalam mempengaruhi profitabilitas pejualan ikan patin asap di kab. Bogor dengan signifikan pada taraf nyata $(0.05$ - 0.1) atau pengaruh pada tingkat kepercayaan $(95$ - $99 \%)$ dan sangat berpengaruh nyata pada tingkat keuntungan usaha yang sedang berjalan, walau masih memungkinkan kiat-kiat baru untuk mempengaruhi perilaku konsumen agar tetap mengkonsumsi ikan patin asap untuk memenuhi kebutuhan protein hewani.

\section{KESIMPULAN DAN SARAN}

\section{Kesimpulan}

Dari hasil penelitian ini dapat diambil beberapa kesimpulan sebagai berikut:

Terdapat pengaruh positif (signifikan) dari perilaku konsumen sebagai indevenden variabel secara individu terhadap jumlah penjualan ikan patina sap di kab, Bogor. 


\section{Saran}

Dari hasil penelitian ini disampaikan beberapa saran sebagai berikut :

1. Diupayakan ada peningkatan tindakan kegiatan promosi dalam memelihara perilaku konsumen, sehingga dapat secara terus menerus, kondusif berpengaruh positif terhadap profitabilitas usaha penjualan ikan patin asap.

2. Peningkatan intensitas promosi, menggalang usaha kemitraan merupakan strategi utama yang disarankan dalam rangka pemilihan tempat yang strategis, sehingga dapat menghidari hight-cost dan meningkatkan penjualan ikan patina sap di kabupaten Bogor

\section{DAFTAR PUSTAKA}

Arnold, HJ. And D.C. Feldman, 1987. Organization Behavior. Mc. Craw-Heill Book Company, New York.

Engel F. James 1, Roger D. Blackwell \& Paul W. Miniard, 1995. Perilaku Konsumen. Jilid 1 - 2. Binarupa Aksara, Jakarta Indonesia.
Hanafi A. 1986. Memasyarakatkan Ideide Baru. Usaha Nasional, Surabaya.

Hersey P. And Ken Blanchard, 1985. Manajemen Perilaku Organisasi Pendayagunaan Sumberdaya Manusia. Penerbit Erlangga, Jakarta.

Istijanto,2005. Aplikasi Praktis Riset Pemasaran.PT.Gramedia Pustaka Umum, Jakarta.

Santoso S. 2000. SPSS Mengolah Data Statistik Secara Profesional. Pustaka Sinar Harapan, Jakarta.

Singariumbun M. Dan S. Effendi, 1989. Metode Penelitian Survei, LP3ES Jakarta.

Slamet M. 2003. Membentuk Pola Pikir Manusia Pembangunan. IPB Press Bogor.

Wahjosumidjo, 1987. Kepemimpinan dan Motivasi. Ghalia Indonesia, Jakarta.

Wasrob N \& Ida Nuraeni.2006. Manajemen Agribisnis. Universitas Terbuka Diknas Jakarta (modul 1 9).

Zanden J. W. V, 1984. Social Psycology. Randow House Inc Ohio State University. 